УДК 338.488.2:640.43]:338.33

https://doi.org/10.52058/2708-7530-2021-9(15)-337-345

Сидорук Анна Вікторівна кандидат педагогічних наук, доцент, доцент кафедри туризму та готельно-ресторанної справи, Запорізький національний університет, вул. Жуковського, 66, м. Запоріжжя, 69000, тел.: (061) 764-45-46, еmail: anna0956564651@gmail.com, https://orcid.org/0000-0002-8466-6912

Конох Олена Свгеніївна кандидат наук з фізичного виховання і спорту, доцент, доцент кафедри туризму та готельно-ресторанної справи, Запорізький національний університет, вул. Жуковського, 66, м. Запоріжжя, 69000, тел.: (061) 764-45-46, e-mail: konoh_o_ye@ukr.net, https://orcid.org/0000-0002-8970-0817

Криволапов Едуард Анатолійович старший викладач кафедри туризму та готельно-рестораннох справи, Запорізький національний університет, вул. Жуковського, 66, м. Запоріжжя, 69000, тел.: (061) 764-45-46, e-mail: edward27772@gmail.com, https://orcid.org/0000-0002-1211-7869

\title{
ОРГАНІЗАЦІЯ РЕСТОРАННОГО ГОСПОДАРСТВА: ФОРМУВАННЯ АСОРТИМЕНТНОЇ ПОЛІТИКИ ТОВАРІВ І ПОСЛУГ
}

Анотація. Стаття присвячена аналізу особливостей формування асортиментної політики товарів і послуг закладів ресторанного господарства. Проаналізовано дослідження багатьох наукових діячів, які займалися питанням формування асортиментної політики підприємства. Висвітлено визначення поняття «асортиментна політика» у сучасній науковій літературі, а також зміст асортиментної політики відповідно підвищенням вимог споживачів щодо кількості, зовнішнього вигляду, якості продукції тощо. Схарактеризовано основні тенденції формування асортиментної політики сучасних ресторанних закладів, а також шляхи іiі вдосконалення. Виокремлено типові проблеми асортиментної політики вітчизняних ресторанів, які можуть виникати через дефіцит і надлишок товарів та послуг. Встановлено, що ефективна й оптимальна асортиментна політика ресторану є головною запорукою його успіху на ринку послуг i результативності діяльності. Визначено основні фактори, які впливають на процес формування асортиментної політики ресторану, принципи і етапи iï побудови. Виокремлено ряд заходів, які рекомендовано застосовувати сучасним закладам ресторанного господарства у процесі формування асортиментної політики. 3'ясовано, що основною задачею закладів ресторанного господарства $\epsilon$ виявлення й усунення виявлених проблем асортиментної політики, вирішення якої дозволить збільшити обсяги реалізації продукції, досягнути конкурентних переваг завдяки унікальному асортименту, залучити нових споживачів, а також 
підвищити привабливість підприємства та збільшити його прибутковість. Запропоновано можливості удосконалення асортиментної політики національних ресторанів за допомогою упровадження інноваційної діяльності.

Ключові слова: заклад ресторанного господарства, асортиментна політика, товар, продукція, послуга, споживач, інноваційна діяльність.

Sydoruk Anna Viktorivna Candidate of Pedagogical Sciences, Associate Professor of the Department of Tourism and Hotel and Restaurant Business, Zaporizhzhia National University, Zhukovsky St., 66, Zaporizhzhia, 69000, tel.: (061) 764-45-46, e-mail: anna0956564651@gmail.com, https://orcid.org/0000-0002-8466-6912

Konoh Olena Yevheniivna Candidate of Sciences in Physical Education and Sports, Associate Professor of the Department of Tourism and Hotel and Restaurant Business, Zaporizhzhia National University, Zhukovsky St., 66, Zaporizhzhia, 69000, tel.: (061) 764-45-46, e-mail: konoh_o_ye@ukr.net, https://orcid.org/0000-0002-8970-0817

Kryvolapov Eduard Anatoliiovych Senior Lecturer at the of the Department of Tourism and Hotel and Restaurant Business, Zaporizhzhia National University, Zhukovsky St., 66, Zaporizhzhia, 69000, tel.: (061) 764-45-46, e-mail: edward27772@gmail.com, https://orcid.org/0000-0002-1211-7869

\section{ORGANIZATION OF RESTAURANT ECONOMY: FORMATION OF ASSORTMENT POLICY OF GOODS AND SERVICES}

Abstract. The article is devoted to the analysis of features of formation of assortment policy of the goods and services of establishments of restaurant economy. The research of many scientists who were engaged in the formation of the assortment policy of the enterprise is analyzed. The definition of the concept of "assortment policy" in the modern scientific literature, as well as the content of assortment policy in accordance with increasing consumer requirements for quantity, appearance, product quality and more. The main tendencies of formation of assortment policy of modern restaurant establishments, and also ways of its improvement are characterized. Typical problems of assortment policy of domestic restaurants, which may arise due to shortage and surplus of goods and services, are highlighted. It is established that the effective and optimal assortment policy of the restaurant is the main guarantee of its success in the market of services and efficiency of activity. It is established that when forming the range of goods and services it is important to analyze and take into account the presence of both external (effective demand, income, level of economic stability, etc.) and internal factors (financial capabilities of the restaurant, purpose, mission and direction, etc.). The main factors influencing the process of forming the assortment policy of the restaurant, the principles and stages of its construction are identified. A number of measures that are recommended for modern restaurant establishments in the 
process of forming the assortment policy are singled out. It was found that the main task of restaurants is to identify and eliminate identified problems of assortment policy, the solution of which will increase sales, achieve competitive advantages through a unique range, attract new customers, and increase the attractiveness of the company and increase its profitability. Possibilities of improving the assortment policy of national restaurants through the introduction of innovative activities are offered.

Keywords: restaurant, assortment policy, product, product, service, consumer, innovation.

Постановка проблеми. Організація ресторанного господарства сьогодення представлена великою кількістю ресторанних закладів різних типів, класів і направленістю, які пропонують споживачам свої варіанти послуг. Аналіз попиту споживчого ринку задає умови, за яких стає необхідність надання потрібного продукту чи послуги у потрібний час i в потрібному місці. Саме тому формування асортиментної політики є одним 3 ефективних інструментів для успішної діяльності підприємств ресторанного господарства, основною задачею якої визначення такого переліку товару і послуг, який буде найбільш кращий для приваблення споживачів та підвищення конкурентоспроможності закладу на ринку надання послуг.

Аналіз останніх досліджень і публікацій. Певні наукові розробки з питань формування асортиментної політики на виробничих підприємствах і підприємствах роздрібної торгівлі досліджували такі вітчизняні та зарубіжні вчені, як Г. Багієв, А. Баришев, Б. Берман, С. Близнюк, С. Гаркавенко, Дж. Еванс, С. Захаров, О. Книшова, Ф. Котлер, М. Окландер та ін. Зокрема, на тему формування асортиментної політики закладів ресторанного господарства звертали увагу такі наукові діячі, як: Брюс Д. Хендерсен [1], Д. Шок Патти [2], С. Дібб [3], М. Мальська [4], В. Найдюк [5], Г. П'ятницька [6] та ін. На сьогоднішній день, розроблення і запровадження обгрунтованої асортиментної політики $\epsilon$ вагомим чинником при реалізації планів у вивченні ринку. Дослідження частин, основ і задач цієї політики $є$ основним завданням теперішніх науковців. В той же час, аналіз наукових робіт показує, що кількість досліджень щодо формування асортиментної політики товарів і послуг закладів ресторанного господарства, в сучасних умовах господарювання, недостатньою.

Метою статті $\epsilon$ аналіз особливості формування асортименту товарів і послуг у закладах ресторанного господарства.

Виклад основного матеріалу. Організація ресторанного господарства представляє особою специфічну тактику господарюючого суб'єкта, спрямовану на підвищення конкурентоспроможності ресторанних послуг і поліпшення умов їх обігу через механізми ціноутворення, рекламу, інноваційну діяльність, вдало сформований асортимент тощо. В ресторанному бізнесі важливим показником конкурентоспроможності являється відповідність асортименту потребам споживачів. Асортиментна політика визначає кількість страв, напоїв та продукції, 
які ресторан пропонує споживачам для задоволення їх потреб [4].

Зазначимо, що в сучасній науковій літературі під асортиментною політикою розуміється діяльність підприємства, яка направлена на формування оптимального товарного складу продукції та послуг, як 3 точки зору підвищення ефективності його діяльності, так і з точки зору максимального задоволення потреб клієнтів [4]. Вона відіграє важливе значення для підприємства будь-якої сфери господарювання, але для ресторанної галузі вона $\epsilon$ найбільш актуальною.

На сьогоднішній день розробка i запровадження обгрунтованої асортиментної політики $є$ вагомим чинником реалізації планів закладів ресторанного господарства.

Асортиментна політика має великий зміст, який пояснюється підвищенням вимог споживачів щодо кількості, зовнішнього вигляду, якості тощо. Виокремимо основні напрямки асортиментної політики (рис. 1).

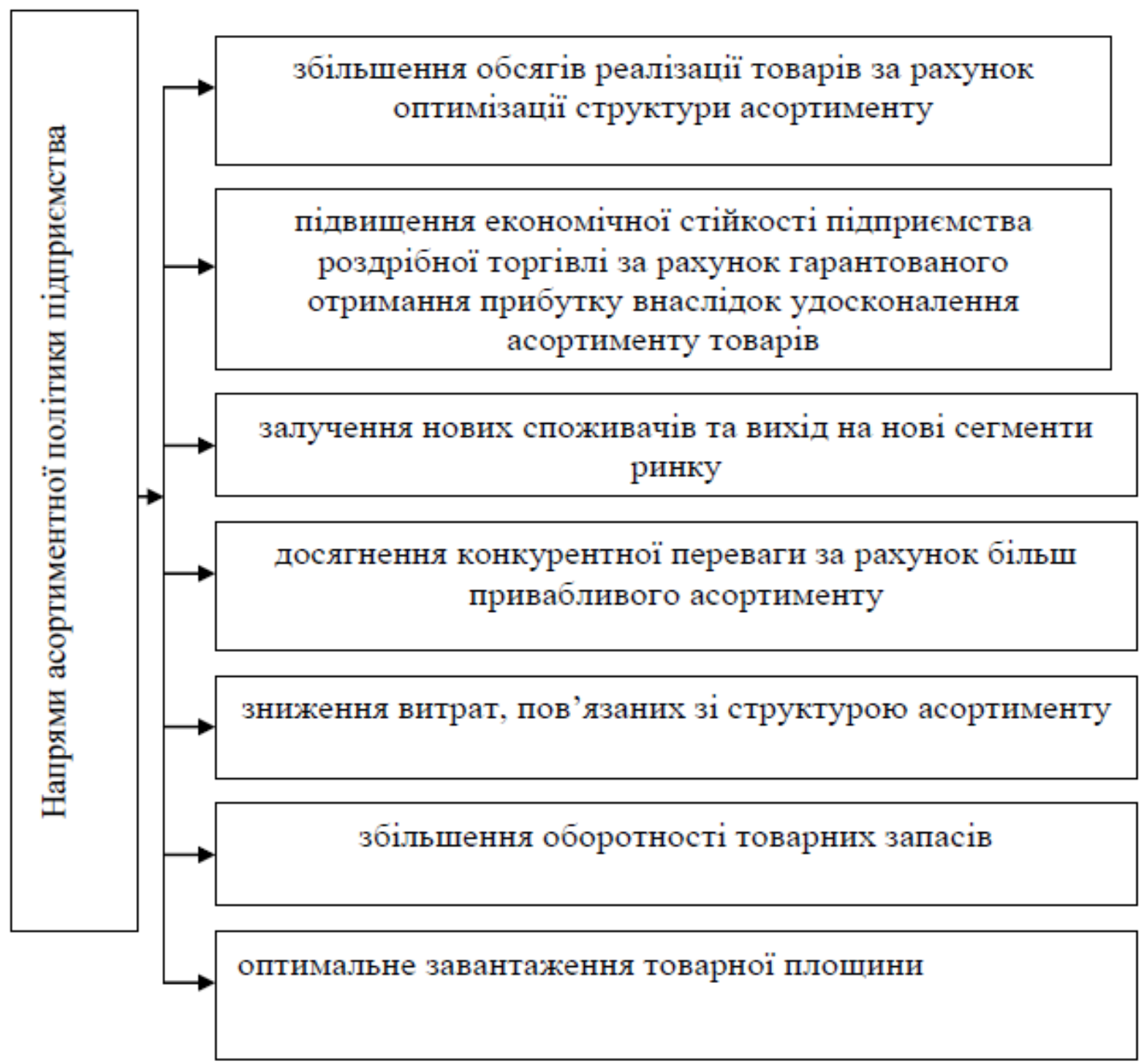

Рис. 1. Напрямки асортиментної політики підприємств [6] 
У сучасному світі асортиментна політика $є$ головним інструментом забезпечення ефективної діяльності закладів ресторанного господарства. Як показує вітчизняна і світова практика, ресторани, які мають проблеми з наявним переліком товарів і послуг, приречені на «провал» та поступовий вихід з ринку. Як зазначає Г. П’ятницька [6], основною причиною такого процесу $\epsilon$ не зовнішньоекономічні фактори, які впливають на діяльність закладу, а саме недосконала асортиментна політика ресторану. В умовах пандемії COVID-19 споживачі ресторанних послуг стали більш вибагливими i частина закладів не змогла їх задовольнити, як наслідок - змушені були закритись. Інша ж частина ресторанів продовжила своє функціонування, за рахунок ефективно сформованої асортиментної політики, навіть в умовах глибокої економічної кризи. У даному випадку для закладів ресторанного господарства важливу роль відіграла швидка адаптація асортиментної політики до сучасних життєвих реалій, а також потреб і можливостей потенційних споживачів.

Деякі автори виділяють такі проблемні питання в управлінні асортиментом товарів і послуг:

- потреба покупців блискавично змінюється, тому підприємство змушене постійно вносити оновлювання у свій асортимент, а це піднімає вимоги до техніко-технологічної основи;

- на підприємствах належним чином не функціонує система управління асортиментом у зв'язку із складністю прогнозування щодо зміни у попиті споживача і відсутністю методики оптимізації асортименту;

- немає чітких критеріїв та інструментів оптимального асортименту на підприємствах;

- конкуренція веде до ситуації, де нова продукція не дозволяє повністю повернути інвестиції у виробництві та збут.

На формування асортиментної політики закладів ресторанного господарства також мають вплив такі фактори, як: оновлення товарного асортименту фірмамиконкурентами, зміни у попиті на продукцію, розвиток торгівлі за соціальними замовленнями, суто виробничі потреби (бажання уникнути незавантаженої потужності, використати відходи виробництва) тощо [3].

Сьогодні змінюється і сама роль підприємств на ринку, так як відбувається їx перехід на активну ринкову поведінку, опрацьовується асортиментна політика на принципах маркетингу. Її найважливішою частиною є перегляд асортименту товарів і послуг, а в деяких випадках суттєва перекваліфікація підприємств.

Вагомою мотиваційною причиною у змінах до вимог ринку стали зміни в попиті і збільшення собівартості продукції, високий попит на нові товари та відносне зменшення попиту на товари, що завзято продавались у минулому. 
У процесі формування асортименту послуг закладів ресторанного господарства необхідно орієнтуватися на певні принципи його побудови, виокремимо їх [7]:

1. Принцип системності (комплексності, синергізму) - всі заходи 3 управління асортиментом повинні розглядатися у взаємозв'язку.

2. Принцип гнучкості - оперативність у реагуванні на мінливу кон'юнктуру ринку.

3. Принцип науковості - управлінські рішення щодо асортименту повинні базуватися на об'єктивній, повній і достовірній інформації про стан та перспективи розвитку потреби, з одного боку, а також можливості щодо иiі задоволення, з іншого боку.

4. Принцип ефективності формування асортименту грунтується на очікуваній рентабельності і величині прибутку.

Процес формування асортименту товарів і послуг закладами ресторанного господарства передбачає проходження декількох етапів, а саме:

I етап - визначення переліку основних груп i підгруп товарів, які реалізуються закладом, виходячи з обраної його товарної спеціалізації та потреб його потенційних споживачів.

II етап - розподіл окремих груп i підгруп товарів між споживчими комплексами постійного та сезонного характеру. Під час проведення цієї роботи слід урахувати розмір торгової площі закладу, а також спеціалізацію підприємств-конкурентів, розташованих у районі його діяльності, особливо вузькоспеціалізованого.

III етап - визначення кількості видів і різновидів товарів у межах окремих споживчих комплексів, тобто глибини товарного асортименту. Основою для проведення цієї роботи є розмір торгової площі та стан пропозиції товарів на регіональному споживчому ринку.

IV етап - розробка конкретного асортиментного переліку товарів і послуг, які пропонуються споживачам.

Під час формування асортиментної політики товарів і послуг ресторанних закладів, слід дотримуватися «золотої середини», так як сучасні споживачі ринку ресторанного бізнесу не завжди позитивно ставляться до великого різноманіття пропонованої продукції, бо можуть відчувати розгубленість, додаткові переживання i, як наслідок, погано орієнтуватися під час вибору продукту.

Отже, для підприємств ресторанного бізнесу негативним є як і надлишок асортименту, так i його дефіцит. Розглянемо, які втрати може отримати ресторанний заклад при не досконалій асортиментній політиці (табл.1). 
Таблиия 1

Результати недосконалого формування асортиментної політики [8]

\begin{tabular}{|c|c|}
\hline $\begin{array}{c}\text { Втрати ресторану при дефіциті } \\
\text { асортименту } \\
\end{array}$ & $\begin{array}{r}\text { Втрати ресторану при } \\
\text { надлишку асортименту }\end{array}$ \\
\hline $\begin{array}{l}\text { Не повне задоволення потреб } \\
\text { споживачів, як наслідок зниження } \\
\text { репутації і втрата ключових } \\
\text { споживачів }\end{array}$ & $\begin{array}{l}\text { Додаткові витрати при розробці } \\
\text { маркетингових заходів для продуктів, } \\
\text { які повільно реалізовуються }\end{array}$ \\
\hline $\begin{array}{l}\text { Зменшення обсягів продаж, що } \\
\text { викликано дефіцитом швидко } \\
\text { рухомих товарів }\end{array}$ & $\begin{array}{l}\text { Витрати на зберігання, переміщення } \\
\text { та утилізацію надлишкової продукції }\end{array}$ \\
\hline $\begin{array}{l}\text { Потенційна втрата клієнтів внаслідок } \\
\text { обмеженого асортименту }\end{array}$ & $\begin{array}{l}\text { Втрати від псування інгредієнтів, які } \\
\text { мають обмежений період зберігання }\end{array}$ \\
\hline Втрата частки лояльних клієнтів & $\begin{array}{l}\text { Надлишковий обсяг асортименту } \\
\text { зумовлює необхідність } \\
\text { необгрунтованих фінансових та } \\
\text { трудових ресурсів }\end{array}$ \\
\hline
\end{tabular}

Проведений аналіз, дає змогу стверджувати, що і надлишок, і дефіцит товарів, веде до витрат підприємства, саме тому, до процесу формування асортименту товарів і послуг слід звертатися дуже уважно.

Перед вітчизняними ресторанами стоїть чітка задача - виявлення й усунення виявлених проблем асортиментної політики, що передбачає саме іiі удосконалення за для підвищення ефективності діяльності закладів.

3 метою удосконалення асортиментної політики першочергово слід звернути увагу на процеси іiі планування та формування. Важливо, щоб асортиментна політика ресторану базувалась не лише на інтуїції власників, але й ураховувала сучасні наукові методи планування і оптимізації, а також результати проведених маркетингових досліджень.

На основі вище визначеного, можемо виокремити ряд заходів, які рекомендовано застосовувати сучасним закладам ресторанного господарства у процесі формування асортиментної політики [8]:

- виявляти продукцію, яку найбільше потребують їх споживачі;

- основну масу асортименту орієнтувати на головну цільову групу споживачів;

- здійснювати опитування споживачів у рамках задоволеності наявним асортиментом;

- використовувати сучасні методи аналізу й оптимізації асортименту (матриця БКГ; матриця Мак-Кінсі; матриця ширина-довжина; метод АВСXYZ- аналізу; математичні ( оптимізаційні) моделі; метод Дібба-Сімкіна тощо); 
- аналізувати світовий досвід інноваційних розробок для розширення асортименту продукції в ресторанах;

- оптимізувати структуру асортименту та їі своєчасне оновлення.

Враховуючи вищезазначену послідовність дій i активно впроваджену інноваційну діяльність можна досягти всіх цілей асортиментної політики ресторанного закладу, яка буде збільшувати товарообіг продукції та послуг. Головною ж умовою вдосконалення асортиментної політики ресторану є активне здійснення інноваційної діяльності, яка забезпечить створення продуктових новинок.

Підтвердженням вище визначеного є пропозиція Л. Коваленко [7], який пропонує національним ресторанним закладам формувати асортиментну політику, використовуючи елементи новаторства й оригінальності як у приготуванні, так і в подачі. Зокрема, він зазначає, що буде орієнтація ресторанів на подільську, карпатську, полтавську, бессарабську кухні зі стравами за оригінальними рецептами, зібраними серед населення (старожилів), на місцевих продуктах. В ресторанних закладах України як в’ізні, так і внутрішні туристи, мають отримати місцеві колорити та стабільну ідентичність (канонічні полтавські галушки, гуцульський банош, подільські вареники, козацький куліш тощо), познайомитися 3 традиціями та технологією приготування страв, особливостями застольного етикету, ставленням до їжі, демонструючи при цьому власну автентичність.

Впровадження продуктових інновацій у діяльність ресторанів забезпечує створення нових продуктів i послуг, що веде до підвищення привабливості закладу та збільшення кількості клієнтів. Тому використання інноваційної діяльності в асортиментній політиці ресторану є важливою умовою підвищення загальної ефективності його діяльності, але не слід забувати про правило «золотої середини».

Оптимізація асортименту ресторанного закладу є невід'ємною умовою його успішного функціонування. В умовах мінливого макросередовища своєчасний аналіз і коректування асортименту може надати підприємству змогу зберегти його позицію на ринку надання послуг, знизити витрати та підвищити рентабельність продажів.

Висновки. Отже, формування й оптимізація асортиментної політики товарів і послуг закладів ресторанного господарства - це складні процеси, недосконале управління якими може призвести до зниження прибутку i регулярної втрати споживачів. Під час формування асортименту товарів i послуг важливо аналізувати та враховувати наявність як зовнішніх (платоспроможний попит, доходи населення, рівень економічної стабільності тощо), так і внутрішніх факторів (фінансові можливості ресторану, мету, місію та направленість та ін.). Слід зазначити, що дотримання умов формування асортиментної політики товарів і послуг надає змогу закладу ресторанного господарства збільшити обсяги реалізації продукції завдяки оптимізації асортименту; досягнути 
конкурентних переваг завдяки унікальності асортименту; залучити нових споживачів до закладу; збільшити оборотність запасів і зменшити витрати, пов'язані 3 їх збереженням; підвищити рівень привабливості ресторану, тим самим збільшити його прибутковість.

\section{Лimepamypa:}

1. Хендерсен Б. Продуктовый портфель. Бостонская консалтинговая груnпа BCG Reviev. 2008. № 02. С. 7-8.

2. Шок Д., Боуэн Дж. Т. Маркетинг в ресторанном бизнесе. М. : Ресторанные ведомости, 2005. $234 \mathrm{c}$.

3. Дибб С., Симкин Л. Практическое руководство по маркетинговому планированию. СПБ. : Питер, 2001. $236 \mathrm{c.}$

4. Мальська М. Ресторанна справа: технологія та організація обслуговування туристів (теорія та практика). К. : ЦУЛ, 2013. 304 с.

5. Найдюк В. Інновації в системі управління підприємствами ресторанного господарства. Сталий розвиток економіки. 2012. № 2. С. 228-233.

6. П'ятницька Г. Вплив інноваційних змін на діяльність підприємств ресторанного господарства. Економіка розвитку. 2013. № 1(65). С. 122-126.

7. Коваленко Л. Асортиментна політика закладів ресторанного господарства України. Економіка і суспільство. 2016. № 5. С. 160-163.

8. Могилова А. Удосконалення асортиментної політики ресторану. Ефективна економіка. 2019. № 11. URL: http://www.economy.nayka.com.ua/pdf/11_2019/6.pdf

\section{References:}

1. Khendersen B. (2008). Produktovii portfel [Product bag]. Bostonskaia konsaltynhovaia hruppa BCG Reviev. № 02, 7-8 [in Russian].

2. Shok D., Bouэn Dzh. T. (2005) Marketynh v restorannom byznese [Marketing in the restaurant business]. M. : Restorannыe vedomosty [in Russian].

3. Dybb S., Symkyn L. (2001) Praktycheskoe rukovodstvo po marketynhovomu planyrovanyiu [Practical guide to marketing planning]. SPB. : Pyter [in Russian].

4. Malska M. (2013) Restoranna sprava: tekhnolohiia ta orhanizatsiia obsluhovuvannia turystiv (teoriia ta praktyka) [Restaurant business: technology and organization of tourist services (theory and practice)]. K. : TsUL [in Ukrainian].

5. Naidiuk V. (2012) Innovatsii V systemi upravlinnia pidpryiemstvamy restorannoho hospodarstva [Innovations in the management system of restaurant enterprises. Sustainable economic development]. Stalyi rozvytok ekonomiky. № 2. 228-233 [in Ukrainian].

6. Piatnytska H. (2013) Vplyv innovatsiinykh zmin na diialnist pidpryiemstv restorannoho hospodarstva [The impact of innovative changes on the activities of restaurants]. Ekonomika rozvytku. № 1(65). 122-126 [in Ukrainian].

7. Kovalenko L. (2016) Asortymentna polityka zakladiv restorannoho hospodarstva Ukrainy [Assortment policy of restaurants of Ukraine]. Ekonomika i suspilstvo. № 5. 160-163 [in Ukrainian].

8. Mohylova A. (2019) Udoskonalennia asortymentnoi polityky restoranu [Improving the assortment policy of the restaurant]. Efektyvna ekonomika. № 11. Retrieved from http://www.economy.nayka.com.ua/pdf/11_2019/6.pdf 